\title{
Isolation of actinomycetes from marine sediments of Muttukadu
}

\section{P. DHEVAGI AND V. KARTHIGA}

Article Chronicle :

Received:

13.09.2016;

Revised :

09.11.2016;

Accepted :

19.11.2016

Key Words :

Marine ecosystem, Actinomycetes, Therapeutic enzymes
ABSTRACT : Among the marine organisms, Actinomycetes had gained special attention due to its major role in recycling organic matter, production of wide varieties of bioactive compounds like enzymes, antibiotics etc. In the present study Actinomycetes producing L-asparaginase activity were isolated from marine sediments of Muttukadu. Nineteen isolates were obtained and among 19, three isolates viz., MK1, MK15 and MK 16 showed maximum asparaginase activity. The enzyme extracted from the isolates was partially purified by salting out with ammonium sulphate precipitation, followed by sephadexG200 filtration. The isolate MK 16 showed high specific activity of $65 \mathrm{IU} / \mathrm{mg}$.

HOW TO CITE THIS ARTICLE : Dhevagi, P. and Karthiga, V. (2016).Isolation of actinomycetes from marine sediments of Muttukadu. Asian J. Environ. Sci., 11(2): 144-151, DOI: 10.15740/HAS/AJES/11.2/144-151.

Author for correspondence :

\section{P. DHEVAGI}

Department of

Environmental Sciences,

Tamil Nadu Agricultural

University, COIMBATORE

(T.N.) INDIA

Email : devagisivaraj@gmail.

com

See end of the article for

Coopted authors' 